\title{
DEVELOPMENT OF HEMP INDUSTRY IN THE EUROPEAN UNION AND LATVIA
}

\author{
Anastasija Vilcina ${ }^{1}$, Gunta Grinberga-Zalite ${ }^{2}$, Kristine MaKovska $^{3}$ \\ Latvia University of Agriculture (Latvia)
}

\begin{abstract}
Hemp is a very valuable plant because each part of it can be used in many ways. It can be used to produce innovative products for building construction, chemical industry, medicine, textile production, consumption, and agriculture. In the article, the authors have aggregated the information about hemp cultivation and processing sector development in the European Union and Latvia and have described its cultivation possibilities, technological processes, and processing capabilities. The aim of the present article was to reveal the topicalities of hemp industry development in the European Union and Latvia. The tasks of the research were to present an overall description of hemp industry development trends in the European Union and to characterize hemp industry development in Latvia focusing on the national support activities and hemp cultivation and processing opportunities. The authors of the article have performed an extensive secondary data analysis to summarize the most important activities that should be done at the national scale to further enhance the development of hemp industry in Latvia.
\end{abstract}

KEY WORDS: hemp, industry, production, Latvia.

JEL CODES: O18, Q16

DOI: http://dx.doi.org/10.15181/rfds.v14i3.876

\section{Introduction}

In nowadays, depletion of non-renewable resources has become a question of the day determining the need for solutions how to replace these resources in the future. At the same time, last but not the least substantial is the necessity to enhance the diversity of agricultural crops both in Latvia and in the European Union (EU). Agriculture is one of the national economy industries that are closely connected not only with the development of a particular country, but also with rural areas as a whole, therefore it is an important factor of the EU rural development as well as stabilising factor of the EU economy.

Hemp is one of the fastest growing crops, and it has a huge potential in different spheres of production. Important is the fact that it is possible to use any part of this plant. Moreover, it is possible to use hemp in

1 Anastasija Vilcina - dr. oec., professor, Latvia University of Agriculture, Faculty of Economics and Social Development. Scientific interests: macroeconomics

E-mail: anastasija.vilcina@1lu.lv

Tel.: +37163021041

2 Gunta Grinberga-Zalite - dr. oec., associate professor, Latvia University of Agriculture, Faculty of Economics and Social Development. Scientific interests: regional economics

E-mail: gunta.grinberga@1lu.lv

Tel.: +37129463545

3 Kristine Makovska - Mg. oec., Latvia University of Agriculture, Faculty of Economics and Social Development. Scientific interests: industry economics

E-mail: kristinemakovska@inbox.lv

Tel.: +37129463545 
many different ways to create innovative products. Therefore, it is topical to evaluate possibilities of industrial hemp cultivation and processing in Latvia.

Although climate conditions in Latvia are suitable for hemp cultivation, hemp cultivation in Latvia has not reached large volumes so far, and hemp is mainly grown in backyard farms. Hemp cultivation and processing is a relatively new area of activity in the traditional grain cultivation. In Latvia, this sector from an economic point of view is comparatively little studied and analysed; however, owing to the increasing demand for natural fibres, lately the development of Latvian hemp fields has been noticed, which should be given a significant role not only in the development of the national economy, but also at the European level.

The aim of the present paper is to reveal the topicalities of hemp industry development in the EU and Latvia and determine the most important activities necessary for enhancing hemp industry growth in Latvia. The tasks of the research are: 1) to present an overall description of hemp industry development trends in the European Union; 2) to characterize hemp industry development in Latvia focusing on the national support activities and hemp cultivation and processing opportunities in Latvia.

In scope of the paper development, the following economic research methods were applied: analysis and synthesis; induction and deduction; monographic method and graphic method. For secondary data analysis, the author has used the publications of European Commission documents, various Internet sources as well as scientific publications and sources of Latvian press.

In the global context, hemp is described as one of the oldest and most diverse crops that humanity has ever known (Clarke, 1999: 272). In Europe, hemp emerged owing to trade connections with Asia. The oldest samples of hemp fabric are found in Germany and are attributed to age 400 years BC. The first hemp paper factory of Spain in the European territory was created in 1150 BC by Spanish moors. Renaissance painters used hemp canvas for their works, and their paint was hemp oil-based (Roulac, 1997: 211).

The most significant changes in the world began after 1937 when the United States (US) Government adopted Marihuana Tax Act, according to which sowing hemp (Cannabis sativa L.) was included in the socalled marihuana plant list. The US Department of Drug Enforcement Activities aimed at strict monitoring of hemp cultivation practically destroyed hemp plantations in North America. Following the practice applied in America, in many European countries, hemp was found to be illegal crop immediately after the Second World War (Inverson, 2000: 302).

By 1990, hemp cultivation in Europe had remained only within 6000 ha in France and some little areas in Spain for producing industrial hemp cigarette paper, which was practiced by using a windmill. However, in the coming years, hemp cultivation volumes gradually grew, in 1997 and 1998 reaching to a record level of 20000 ha, and from 2001 to 2006 retained a stable performance. In 2007 and 2009, its price reached the highest point, which was mainly due to the price compared with the main competing crops such as wheat. Such situation refers to so-called niche crops of high dependency on the current rivalry with agricultural land use. Because in 2010 and 2011 there has again been a sharp rise in prices of agricultural produce, nowadays it becomes more and more difficult to convince farmers to grow hemp (Poitrowski, Carus, 2011).

The main reasons why hemp is regarded as a high-productivity, multi-dimensional use non-food crop with an increasing importance in the agricultural and industrial production are as follows.

1) Hemp can be used as a raw material for industrial and energy production; 30-40\% of its stem can be used for high-quality production of fibre (paper, composite materials, and car manufacturing).

2) Hemp is potentially suitable crop for development according to the principles of sustainable agriculture providing an alternative land use as well as being considered as a rotation exchange plant. Moreover, hemp offers a variety of advantages such as reducing the use of pesticides while increasing the yield of the next crop rotation programme.

3) Hemp produces yield each year, thus farmers do not require investment in the long term as hemp brings profits in the same year; besides, hemp has similar production technology to already widely grown traditional crops.

4) It is possible to use hemp in pharmacy, and it already now has such market. 
5) In the future, hemp could play a role in the land remediation of heavy metals (Rannali, Venturi, 2004: 1-6).

Consequently, hemp cultivation and processing in scope of agricultural production can promote the manufacturing of special high value added products.

\section{Hemp cultivation in Europe}

In nowadays, hemp seed is grown worldwide, and by increasing people's concern for the ecological situation and preservation of the environment, the demand for natural fibres (including hemp) increases. The largest hemp producing countries in the world are China, North Korea, and Canada. In China and North Korea, hemp is annually sown within approximately 80000 hectares, in Canada - about 10000 hectares. Among the European Union countries, most hemp is grown in France, Germany, the United Kingdom, and the Netherlands. Overall, in Europe 22,000 to 24,000 tons of hemp fibre and 44,000 to 48,000 tons of hemp sheaves are annually produced (Hemp and its cultivation, 2011).

In 2013, hemp volumes in Europe increased and reached about 16000 ha (in 2012 hemp volume accounted for $14000 \mathrm{ha}$ ). Average planned fibre extraction is 2.0 to 2.2 tons per ha. The largest areas of hemp are grown in France, which provides about $80 \%$ of all the EU hemp fibre. Hemp fibre sales in 2012 accounted for 30000 tonnes, including technical fibre paper industry -20, 000 tons and technical (short) fibre in other areas - 10000 tonnes (used mainly in the manufacture of insulation materials and bio-composites production). Market experts have found out that France, the Czech Republic, and Germany in 2014 are planning to increase their hemp areas. The study of hemp market prices in 2012-2013 shows that the price of technical hemp fibres is approximately $600-800 \mathrm{EUR} / \mathrm{t}$, whereas the price of technical fibre of hemp used for paper production is $350-400 \mathrm{EUR} / \mathrm{t}$, but the price of hemp sheaves - $200 \mathrm{EUR} / \mathrm{t}$ (stable price with upward trend), and the price of hemp seed is approximately $1200 \mathrm{EUR} / \mathrm{t}$ (in 2002, the price was $250 \mathrm{EUR} / \mathrm{t}$, but in 2012 - already $1000 \mathrm{EUR} / \mathrm{t}$ ). The hemp fibre price studies show that there has been a $15 \%$ increase in average prices compared with 2011. Moreover, next year experts predict flax and hemp area increase by 7-10\% in the EU countries, and increase in the demand for hemp seed for food and cosmetics in the EU countries will grow by $10-20 \%$, for organically grown seeds - even up to $100 \%$ (Tomsone, 2013; European Industrial Hemp Association, 2014).

\section{Hemp cultivation in Latvia}

Hemp cultivation in Latvia has historical parallels with Europe. Similar to the EU, interest in hemp cultivation in Latvia has increased during the last years alongside with hemp-cropped areas. In the past, hemp was more prevalent among farmers. They occasionally sowed it in old orchards abandoned with weeds. Nowadays, when a large area of agricultural land is weed infected with degraded and compacted soil, it would be worth again start paying attention to the cultivation of hemp. The rich foliage of hemp suppresses weeds and forms a good soil structure. In Latvian farms, there are many suitable places for hemp cultivation - both in the backyard crop areas and in cultivated fens (Antonijs, Drikis, 2000: 16).

Beginning with 2015, the EU provides that $95 \%$ (currently $85 \%$ ) of passenger car parts must be manufactured of such materials that can be recycled and reused repeatedly. Each car requires about $30 \mathrm{~kg}$ of natural fibres. Based on the estimates, each year Germany releases five million cars, and for only this purpose already 150 thousand tons of hemp fibre is needed annually, thus increasing market opportunities of hemp. Hemp natural products could be very useful also for house insulation, which is a very topical issue in Latvia, but there is a problem that building regulations regarding technical standards for hemp fibre-based materials have not yet been established in Latvia. Unfortunately, hemp is not included in the catalogue of varieties cultivated in Latvia. Nevertheless, Latvian energy guidelines adopted for 2007-2016 stipulate that in the period up to 2020 it is intended to reduce the specific heat consumption of buildings from $220 \mathrm{~kW} / \mathrm{m}^{2}$ to $150 \mathrm{~kW} /$ 
$\mathrm{m}^{2}$. Consequently, it will be necessary to bring clarity in this sphere to be able to use the financing of the EU structural funds (Bumane, 2010: 32-36).

It is also important to emphasise that hemp production not only enhances biologic diversity, but also helps to retain landscape diversity and natural heritage of rural areas of Latvia. By providing the manufacturing of previously mentioned renewable resources, it would be possible to maintain and perhaps even increase the number of workplaces in Latvia regions. Considering the specific characteristics of the fibre, it is necessary to search for ways to adapt them to other spheres. As technology evolves, new applications of the material can emerge. Today, hemp is processed to manufacture thousand kinds of products that are both cheaper and environmentally cleaner. Hemp is used in textile, food, pharmaceutical, furniture, construction, oil and gas, pulp-paper, ore mining, energy, steel, radio and ship manufacturing, communications, and medical industries. Moreover, fibre is used to manufacture twisted rope, cables, technical fabrics (canvas, tarpaulin cloth bag) and packaging materials in the fishery sector. Hemp fibre materials as well are used in furniture and footwear, special clothes, bags, curtains and accessories for the manufacture of fire-fighting, car covers, medical and perfume products. Fine hemp a fabric is used to manufacture summer clothes and denim, but hemp pulp can be used for manufacturing of valuable and high-quality paper (Freivalde, Ulme, 2009: 5).

\section{National support for hemp cultivation in Latvia}

For the coming years in Latvia, the intention that has a national importance is to use each hectare of agricultural and forest land productively, in particular, to achieve more efficient agricultural production providing that 2 million ha of agricultural land are used alongside with increasing the efficiency of farms, which would bring more value added and higher income for farmers, thus increasing the amount of taxes paid and stimulating economic growth. Latvian Rural Development Programme for 2014-2020 strategy solution is subordinated to the medium-period planning document - Latvian National Development Plan 2014-2020 (NAP 2020). Whereas National Development Plan 2020 (NDP 2020) is hierarchically highest national level of medium-term planning document. This document also ensures a transparent link with the European Union planning documents and their set priorities and thematic objectives. In the directions of the NDP 2020 activities are:

- manufacturing of high-performance export production and internationally competitive services;

- $\quad$ ensuring outstanding business environment.

According to the legal enactments, in Latvia the producer groups that have obtained the status of compliance to the EU requirements are co-operative societies of agricultural and forestry services. Owing to the favourable EU and national support policy regarding the development of cooperation, at the end of 2012 in Latvia 122 agricultural services' cooperatives in dairy and grain sectors operated. At this period, of the previously mentioned 122 agricultural services' cooperative societies, 42 operated in the grain sector. One of the strongest cooperatives can be observed in the grain industry, in which $32.7 \%$ of the total Latvian output is marketed through cooperative societies. Currently, not only hemp can be associated with unexploited potential, but is also flax, fruit, vegetables and beekeeping industry cooperation. In the future, along with general cooperative development, it is also necessary to motivate cooperatives for processing activities, which would enable them producing the products with higher value, added as well as increased the sales and profits of cooperative societies. By implementing vertical cooperation model, it would be necessary to focus on acquisition of sales markets, searching for marketing and sales opportunities for goods produced by cooperative members (Latvian Rural Development (...), 2014) (Regulations on the State (...), 2010).

According to the Latvian Rural Development Programme for 2007-2013, the representatives of the hemp sector could apply for such support measures as "Support for semi-subsistence farms undergoing restructuring", "Support for young farmers" and "Modernisation of farms". These programmes provided an opportunity for young entrepreneurs, representatives of hemp sector to start or expand their business, which in this case is directly related to hemp cultivation and processing (Lielbarde, 2012). 
Last but not the least issue in scope of the Common Agricultural Policy reform is equalisation of direct payments (DP) because, both now and in the future (after 2013), Latvia is going to receive the least DP per one hectare of agricultural land among all the EU member states. According to the EC legislative proposal, Latvia starting with 2017 would receive only $54 \%$ of the average EU level or approximately $141 \mathrm{EUR} / \mathrm{ha}$. Whereas, according to the project proposal prepared by the European Parliament, Latvia starting with 2017 would receive $65 \%$ of the average EU level or approximately $172 \mathrm{EUR} / \mathrm{ha}$. It is important to emphasise that income and competitiveness of Latvian farmers in the EU market largely depend on the amount of direct payments. The future trends of DP also directly affect the development of hemp sector, which, in the case of positive indicators, would result in more incentives for hemp cultivation in agricultural land areas (Description of agricultural situation (...), 2013; Granting National Subsidies (...), 2013).

\section{Opportunities for hemp cultivation and processing in Latvia}

Although Latvia does not cover all hemp supply possibilities, its vision of the future is marked in a number of ways - insulation materials, polymer composite materials used in the construction and automotive industry; and Latvian hemp fibre is already now used in the manufacturing of threads and ropes. It is also possible to use hemp sheaves which, when mixed with lime, can be used in building construction. Now the tests of such material conductivity and resistance are being carried out in Latvia. Sheaves can also be applied as a bedding material in horse breeding and poultry farming. In Latvia, such use of sheaves is not popular yet, but in Europe, especially in England, sheaves' beddings are used in large amounts. Moreover, in some countries today there is even sophisticated nanotechnology used to manufacture so-called intelligent materials - those that are bullet-proof and fire-resistant, which is another challenge for Latvian manufacturers to aspire to (Zalane, 2012: 28-29).

It is envisaged that at the global scale in the next years the amount of fossil raw materials and synthetic fibre production volumes will gradually decrease. Nevertheless, the demand for fibre materials is growing as they are more and more used for new product production. Therefore, it is vitally important to increase the use of Latvian natural renewable resources, i.e. flax and hemp fibre, oil and sheaves in manufacturing such products as fibres, yarns, rope, felt, fabric, knitting, thermal insulation and composite materials. Hemp fibre and its products fictionalization is a new trend in the world, which forms the basis for sustainable economic growth on the renewable natural resource base, because hemp is eco-crop. In order to obtain a competitive product quality, it is vital to both have appropriate environmental conditions, production technology, and genetic potential. In Latvia, complex scientific research on hemp production facilities, technology and utilization prospects in various sectors of the economy have not been conducted so far. Therefore, it is necessary to activate research to find out Latvia's perspectives in hemp cultivation and use as well as evaluate its potential contribution to sustainable agriculture and environment interaction (Strazds etc., 2012: 52).

As shown in Figure 1, hemp cultivation can become a perspective industry owing to the fact that it is possible to use both seeds of the plant and its fibre, thus providing potential for its growing and processing. In the conclusion, the authors have aggregated the most common possibilities for hemp use. In food industry - oil, margarine, food additives, canned fish, confectionery, hemp beer, leaf juice drink hemp milk. Industrial products - varnishes and paints, inks, solvents, coatings. In medicine - medical cosmetics. In cosmetology - soaps, shampoos, creams. In bio-energy extraction - bio-diesel production. In animal feed - poultry, fish food. In oil industry - animal nutrition (for livestock as feed additive). In construction and insulation materials - panels, sheave concrete blocks, plastering. In heat and energy - production of briquettes and granules, bio-ethanol and methanol production, the use of biomass bio-oils extraction, biogas, and fuel compressed (round) form. In the paper industry - filter paper, writing paper, bonds, cash, packaging paper. In agriculture - beddings, substrates, mulch. In chemical industry - for plastic improvement. In textile - threads, cords, ropes, mats, tarpaulins, geo-textiles, agro-textiles, brake pads, gaskets, filter material, denim fabrics, sails, tarpaulins, bags, curtains, belts, table linen, and bed linen. 

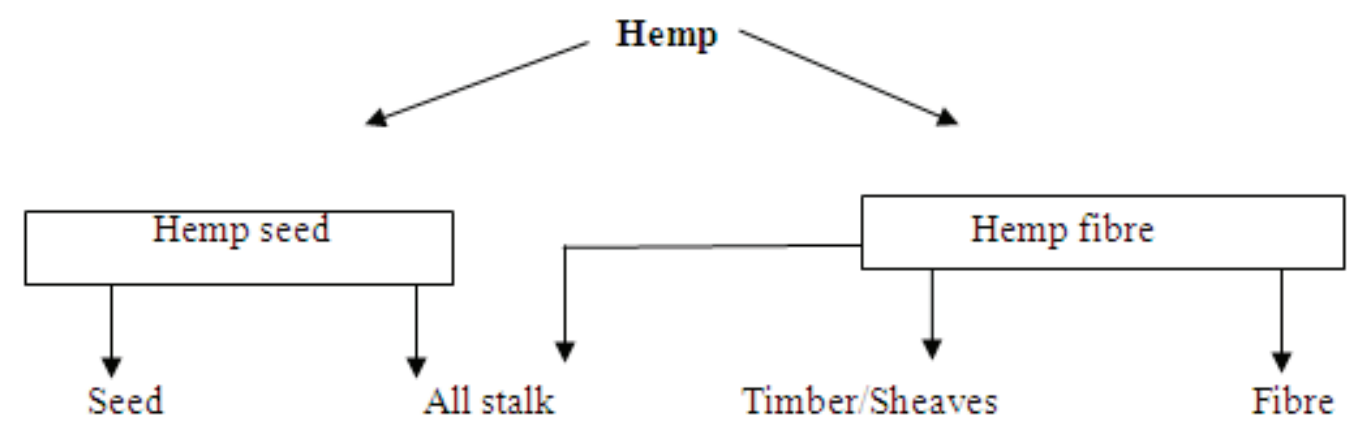

\begin{tabular}{|c|c|c|c|}
\hline Production of food & $\begin{array}{c}\text { Building and } \\
\text { insulation materials }\end{array}$ & Paper industry & Technical fibre \\
\hline Industrial products & $\begin{array}{c}\text { Heating and power } \\
\text { supply }\end{array}$ & Agriculture & $\begin{array}{c}\text { Textile } \\
\text { manufacturing }\end{array}$ \\
\hline Medical goods & & Chemical industry & \\
\hline Cosmetology products & & $\begin{array}{c}\text { Building and insulation } \\
\text { materials }\end{array}$ & \\
\hline Bio-energy & & Heating and power supply & \\
\hline Animal feed & & & \\
\hline Oil by-products & & & \\
\hline
\end{tabular}

Figure 1. Opportunities for hemp use

Source: Makovska, 2014: 61

The diverse use of hemp in different areas may be the reason for many young entrepreneurs to choose hemp cultivation as one of its core activities. This is evidenced by the fact that although hemp direction in Latvian is only beginning to trigger, some of the businesses have already found their niche in the hemp sector and are successfully developing.

Latvian enterprises that are currently active in hemp industry are Ltd. "Hemp Eco Systems Latvia" (ecological materials like hemp lightweight concrete, used for building construction); Ltd. "Kichi" (textiles), Ltd. "Sativa Fibris" (pre-treatment factory), Ltd. "Remember Brothers" (houses of hemp sheaves' concrete panels); Ltd. "Transhemp" (pre-treatment factory), Ltd. "Zalers", Ltd. "Baltiks East", Ltd. "Larelini", Ltd. "L.N.A.", Ltd. "Iecavnieks" (produce hemp spread); farm "Adzelviesi” (pure hemp butter), Latvian hemp breed "Purini"), farm "Kalnakalvi", farm "Raudoviski", Ltd. "Limbazu tine" (weaving of hemp fabric), Ltd. "Straupe" and farm "Sidrabi" - hemp butter (Association of Latvian hemp Growers and Processors, 2014).

\section{Conclusions}

In nowadays, the necessity for hemp cultivation in the EU is determined by the need to enhance the diversity of agricultural crops as well as by the fact that hemp is one of the fastest growing crops and it has a huge potential in different spheres of production. The authors' study revealed that it is possible to use hemp in many different ways to create innovative products. Therefore, hemp industry development can be favourable both for the EU rural development and as a stabilising factor of the EU economy. 
Authors' study gives evidence that although climate conditions in Latvia are suitable for hemp cultivation, hemp cultivation in Latvia has not reached large volumes so far and can be regarded as a relatively new area of activity in the traditional grain cultivation. Moreover, from an economic point of view, hemp industry development possibilities have been comparatively little studied and analysed so far. Therefore, it is topical to evaluate possibilities of industrial hemp cultivation and processing in Latvia, which could be done by involving alongside with the representatives of the Ministry of Agriculture also researchers from Latvia scientific institutions. Accordingly, hemp sector development should be promoted, based on deep research work and economic evaluation. As analysis of hemp use in different sectors of economy revealed, state bureaucracy currently could be mentioned as a hindering factor in Latvia, nevertheless it is evident that the new sector's acquisition could give to Latvia plenty of opportunities to promote business directly and possibly provide new workplaces, especially in the regions of Latvia.

Economic evaluation of hemp sphere, significance of its support tools significance, and assessment of hemp cultivation and processing capabilities are the basis for identifying the value and importance of hemp in Latvian industrial production.

\section{References}

Antonijs, A., Drikis, J. (2000). Kanepes. Jelgava, 16 lpp.

Bumane, I. (2010). Kanepju vilinājums - risks vai pelna? AgroTops, Nr. 5, 32-36.lpp.

Clarke, R. C. (1999). Botany of the Genus Cannabis, Chapter 1. In: P. Rannali (ed.). Advances in Hemp Research. USA: New York, Food Products Press, p. 272.

EU Agriculture - Statistical and Economic Information. (2012). Available at: http://ec.europa.eu/agriculture/statistics/ agricultural/2012/index_en.htm [accessed 2014-03-02].

European Industrial Hemp Association. (2014). Available at: http://www.eiha.org/index.php [accessed 2014-03-02].

Freivalde, L., Ulme, A. (2009). Atjaunojamo izejvielu attistiba Latvijas teritorija. RTU Zinatniskie raksti: Materialzinatne, 9.serija, 4.sejums, 5 lpp.

Inverson, L. L. (2000). The Science of Marijuana. USA: New York, Oxford University Press, p. 302.

Kanepes un to audzesana. (2011). Available at: http://www.laukutikls.lv/lauksaimnieciba/zinas/2336-kanepes_un_to_ audzesana [accessed 2014-03-03].

Latvijas kanepju audzetaju un parstradataju biedriba. (2014). Available at: http://company.lursoft.lv/latvijas-kanepjuaudzetaju-un-parstradataju-asociacija [accessed 2014-04-10].

Latvijas Lauku attistibas programma 2014-2020 gadam. (2014). Politikas planosanas dokuments. Available at: https://www.zm.gov.lv/public/files/CMS_Static_Page_Doc/00/00/00/39/25/LAP_2014_20_10032014.pdf [accessed 2014-04-01].

Lauksaimniecibas nozares apraksts. (2012). Available at: http://www.viaa.gov.lv/files/free/12/14912/apraksts_lauksaimnieciba_final_07052012.pdf [accessed 2014-03-12].

Lauksaimniecibas situacijas apraksts un nozares vajadzibu analize Latvijas lauku attistibas plana 2014-2020. gadam izstradei. (2013). Available at: http://www.laukutikls.lv/pielikumi/4005_lauksaimniec\%c4\%abbas situ\%c4\%81cijas_apraksts_2013.pdf [accessed 2014-02-18].

Lielbarde, Z. (2012). Nakotnes izejviela - industriala kanepe. Available at: http://www.lvportals.lv/skaidrojumi. php?id=246363 [accessed 2004-15-02].

Makovska, K. (2014). Evaluation of Hemp Cultivation and Processing in Latvia. Master's thesis, 104 p. Jelgava, Latvia University of Agriculture.

Noteikumi par valsts un Eiropas Savienibas lauku attistibas atbalsta pieskirsanu, administresanu un uzraudzibu vides un lauku ainavas uzlabosanai. (2010). MK 2010. gada 23. marta noteikumi, Nr. 295. Available at: http://likumi.lv/ doc.php?id=207288 [accessed 2014-03-01].

Par valsts subsidiju pieskirsanu. (2013). Available at: http://org.daba.lv/LLZC/apsveikums.html [accessed 2014-0215].

Piotrowski, S., Carus, M. (2011). Latvijas kanepju nozares iespeju prieksizpste. Nova - Institut GmbH; Projekta Nr. 2010/0203/2DP/2.1.2.0/10/APIA/014 Dabisko skiedraugu audzesanas un parstrasdes iespeju izpete un klasteru izveide ietvaros. Available at: http://www.turiba.lv/f/Latvijas_kanepju_nozre.Prieksizpete.pdf [accessed 2014-03-17].

Rannali, P., Venturi, G. (2004). Hemp as a Raw Material for Industrial Applications. Euphytica, Vol. 140, No. 1-2, p. $1-6$. 
Roulac, P. (1997). Hemp Horizons: The Comeback of the Worlds Most Promising Plant. Vermont, USA: Chelsea Green Publishing Co., p. 211.

Strazds, G., Stramkale, V., Laizans, T. (2012). Ieteikumi rupniecisko kanepju audzetajiem un parstradatajiem. Praktiska rokasgramata. Riga: Izdevejs SIA "Biznesa augstskola Turiba”, 52 lpp.

Tomsone, I. (2013) Spriez par linu un kanepju tirgu. Available at: http://www.laukutikls.lv/copa_cogeca/307lini_un_ kanepes/4088spriez_par_linu_un_kanepju_tirgu_[accessed 2014-03-02].

Zalane, L. (2012). Kanepem jacinas àr rapsiem un kviesiem. Lietiska Diena, Nr. 16 (18 apr.) 28-29. lpp.

\title{
KANAPIŲ PRAMONÉS VYSTYMAS EUROPOS SĄUUNGOJE IR LATVIJOJE
}

\author{
Anastasija Vilcina, Gunta Grinberga-Zalite, Kristine Makovska
}

Latvijos žemès ūkio universitetas (Latvija)

\section{Santrauka}

Kanapès yra labai vertingas augalas, nes ịvairiais būdais galima panaudoti visas jo dalis. Jos gali būti naudojamos novatoriškų produktų statybos pramonei gamyboje, chemijos pramonèje, medicinoje, tekstilèje, žemès ūkyje. Šiame straipsnyje autoriai apibendrino informaciją apie kanapių auginimo ir apdirbimo sektorių plètrą Europos Sajungoje ir Latvijoje, apibūdino jų kultivavimo galimybes, technologinius procesus ir apdirbimo pajègumus. Šio straipsnio tikslas - atskleisti kanapių pramonès vystymo aktualumą Europos Sajungoje ir Latvijoje. Straipsnio uždaviniai: pateikti bendras kanapių pramonės vystymosi Europos Sajungoje tendencijas ir apibūdinti kanapių pramonės vystymąsi Latvijoje, atkreipiant dėmesį ị valstybės paramą ir kanapių auginimo bei apdirbimo galimybes. Autoriai atliko išsamią antrinių duomenų analizę ir apibendrino pagrindines veiklas, kurios turi būti igyvendinamos valstybiniame lygmenyje, kad kanapių pramonè Latvijoje būtų intensyviai vystoma.

PAGRINDINIAI ŽODŽIAI: kanapés, pramoné, gamyba, Latvija.

JEL KLASIFIKACIJA: O18, Q16 